\title{
The United States and Russian Governments Involvement in the Syrian Crisis and the United Nations' Kofi Annan Peace Process
}

\author{
Ken Ifesinachi Ph.D \\ Professor of Political Science, University of Nigeria \\ kifesinachi@yahoo.com \\ Raymond Adibe \\ Department of Political Science, University of Nigeria \\ raymondadibe@yahoo.com
}

Doi:10.5901/mjss.2014.v5n27p1154

\begin{abstract}
The inability of the Syrian government to internally manage the popular uprising in the country have increased international pressure on Syria as well as deepen international efforts to resolve the crisis that has developed into a full scale civil war. It was the need to end the violent conflict in Syria that informed the appointment of Kofi Annan as the U.N-Arab League Special Envoy to Syria on February 23, 2012. This study investigates the U.S and Russian governments' involvement in the Syrian crisis and the UN Kofi Annan peace process. The two persons' Zero-sum model of the game theory is used as our framework of analysis. Our findings showed that the divergence on financial and military support by the U.S and Russian governments to the rival parties in the Syrian conflict contradicted the mandate of the U.N Security Council that sanctioned the Annan plan and compromised the ceasefire agreement contained in the plan which resulted in the escalation of violent conflict in Syria during the period the peace deal was supposed to be in effect. The implication of the study is that the success of any U.N brokered peace deal is highly dependent on the ability of its key members to have a consensus, hence, there is need to galvanize a comprehensive international consensus on how to tackle the Syrian crisis that would accommodate all crucial international actors. We recommended that there is need for a negotiated solution that will involve a compromise agreement by the conflicting parties on the basis of mutual consent since the zero-sum nature of the Syrian conflict in which both regime and its opponents seek total victory make political settlement elusive.
\end{abstract}

Keywords: Annan Peace Process, Syrian Crisis, Strategic Interest, UN Security Council, Zero-Sum Game

\section{Introduction}

Since taking office in 2000, President Bashir al-Assad has offered and retracted the prospect of limited political reform in Syria despite the serious socio-economic and political challenges that the nation of Syria face. As noted by Sharp and Blanchard (2012B), some of these challenges which include high unemployment, high inflation, limited upward mobility, rampant corruption, lack of political freedom, and repressive security forces have fuelled persistent opposition to the Syrian authoritarian government. As unrest emerged in other Arab countries in early 2011, limited calls for organized reform protests in Syria failed, but the government torture of children involved in an isolated incident in the southern town of Dara'a in March 2011, provided a decisive spark for the emergence of demonstrations (Sharp and Blanchard, 2012B). The government use of force against demonstrators in Dara'a and later in other cities created a corresponding swell in public anger and public participation in protests. Faced with a vicious response by government forces, the initially nonviolent uprising has progressively changed into an armed rebellion and civil war between government forces loyal to President Assad and opposition forces led by the Free Syrian Army (FSA), a group made up of largely soldiers who defected from the Syrian army (Dunne, 2012). Nearly 70,000 people have died in the conflict to date, and one million refugees have fled into neighboring countries, with another 5,000 joining them everyday (Dunne, 2012). A UN estimate further suggest that two and a half million Syrians are internally displaced. The Syrian civil war has received significant international attention, and both the Syrian government and the opposition have received support from foreign powers. As noted by Dunne (2012), the Syrian crisis is no longer a confrontation between the rulers and the ruled, but a looming multilateral struggle between varying foreign interest with the very identity of Syria, and its future as a potential democracy at stake. 
The uprising in Syria has provided an opportunity for both the United States and Russian governments to improve and consolidate on their bilateral relations with the country either through support or non-support for the embattled government. They see cordial bilateral relations with Syria as a means to further broaden and strengthen their spheres of influence in the Middle East. It is therefore not surprising that the United States and Russian governments have been very vocal foreign actors since the Syrian unrest began. While the United States' support has been for the opposition group calling for President Assad to step down in order to usher in a transition programme, Russia, on the other hand, has supported many multilateral processes aimed at establishing a political transition in Syria, but has refused to back any demand for President al-Assad to step down as a pre-condition for talks (Dunne, 2012). Beyond rhetoric's however, both the United States' and Russian governments have made considerable efforts to provide strategic supports that will help advance and secure their interests in post-war Syria.

The United Nations' Security Council approval of the appointment of Kofi Annan as the U.N-Arab League Special Envoy to Syria signaled international commitment to resolve the Syrian crisis in a non-partisan manner, ruling out the possibility of any form of direct military intervention in support of any of the conflicting parties by the U.N. The aim of the peace deal brokered by Kofi Annan was to establish a long-term ceasefire that would support the opening of a national dialogue between the Syrian government and opposition groups on Syria's political future (Sharp and Blanchard, 2012B).

The Annan six-point peace plan specifically called for:

- A Syrian-led political process to address the aspirations and concerns of the Syrian people;

- A U.N-supervised cessation of armed violence in all its forms by all parties to protect civilians;

- All parties to ensure provision of humanitarian assistance to all areas affected by the fighting; and to implement a daily two-hour humanitarian pause;

- Authorities to intensify the pace and scale of release of arbitrarily determined persons;

- Authorities to ensure freedom of movement throughout the country for journalists; and

- Authorities to respect freedom of association and the right to demonstrate peacefully (www.un.org/news/ press/does/2012).

However, the involvement of the U.S and Russian governments in the Syrian crisis have been on partisan basis with both nations reported to have provided various forms of financial and military assistance to the opposing actors in the conflict. These assistances were aimed at giving a comparative advantage to the group they align with in the conflict over the other. The partisan involvement of the U.S and Russian governments in the Syrian crisis meant that both governments, despite being permanent members of the U.N Security Council that sanctioned the Annan peace process, also adopted certain unilateral measures directed at giving an extra advantage to the party they aligned with in the conflict. This study therefore attempted an investigation of the effect of the divergence in the nature of the United States and Russian governments' involvement in the Syrian crisis on the Kofi Annan peace process.

\section{Theoretical Explanation on why the Annan Peace Process for Syria Failed}

The resignation of Kofi Annan as the UN-Arab League Special Envoy to Syria by the end of August 2012 as the Syrian government remained entangled in a violent conflict of survival with the opposition force led by the Free Syrian Army (FSA) signaled the collapse and failure of his peace process for Syria. The adoption of the two persons' zero-sum model of the game theory in the analysis of the United States and Russian governments' strategic and economic interest in Syria explains better why the Annan peace process failed.

Plano and Riggs (1973:33) defined game theory as "a body of thought dealing with rational decision strategies in situations of conflict and competition, when each participant or player seeks to maximize gains and minimize losses". Schelling (1960) defined game theory as the formal study of the rational, consistent expectations that participants can have about each other's choices. Game theory is generally played according to what is called the minimax strategy. This implies that players try to minimize their maximum possible losses. Varma (1975) itemized the six fundamental features of game theory as: (i) Rational Behaviour; (ii) Strategy; (iii) Play-Off or Outcome; (iv) Rules of the Game; (v) Alliances; and (vi) Solution. In the two person's zero-sum model of game theory, there are two plays and the gain of one equal the loss of the other. That is, the victory and loss always cancel each other out.

The United States and Russian governments represent two rational actors engaged in a game of conflict and cooperation in the Middle East, and Syria in particular. The zero-sum nature of this conflict emanates from the fact that the U.S. gains in the Middle East, and Syria in particular strategically amounts to Russia's loss. For instance, while regional stability of the Arab world is crucial to the U.S government in ensuring reduction and stability of global oil prices that beneficial to her as an oil importing nation, instability in the region however leads to soaring of oil prices in the global 
market, a situation favourable to Russia as an oil-exporting country. The influence weighed by the Syrian government in promoting or marring the Arab-Israeli peace process, therefore, makes the nation of Syria of utmost importance to the U.S. and Russia governments. While the United States' government favours a regime change in Syria since it considers the Assad regime to be a threat to her interest in the Middle East, the Russian government has cordial bilateral relations with the Assad regime and continues to provide the regime with nuclear heads as a strategic way of deterring Israeli from attacking Syria.

The United States government adopted certain strategies in her attempt to oust the Bashir al-Assad's government from power. Such strategies include imposing some economic sanctions on the Syrian government to weaken the regime's economic base; providing opposition coalition forces with arms to fight the government forces as well as giving them funds; and championing the course for the imposition of multilateral sanctions that could lead to foreign military intervention in the Syrian crisis. The Russian government, on the other hand, continues to provide financial aids to the regime so as to cushion the effects of the economic sanctions imposed on the Assad led regime. The Russian government admitted to have printed currency for the Assad government in Syria which as ensured the availability of cash to pay government soldiers as well as mercenaries fighting for the regime. It has also supplied the regime with more sophisticated ammunition to help the government forces, and repeatedly vetoed every attempt to impose a multilateral sanction on the Syrian government that may lead to any form of foreign military intervention.

The United States and Russian governments have carefully adopted their respective strategies as a way of achieving their objective or pay-off. The U.S government aim is to oust the President Bashir al-Assad led regime and replace it with a new government, formed by the coalition of opposition groups that would improve Syria's bilateral relations with the United States, and extend the U.S government sphere of economic interest to Syria. Sharp (2010) noted that the hostility in the U.S-Syria bilateral relations undermined the ability of U.S Multinational Corporations to operate in Syria and it resulted in the U.S firms' loss of business contracts in Syria worth billions of dollars. The Russian government on the other hand, aim to maintain regime status-quo in Syria since a change in power to a more U.S friendly government, will not only threaten Russia's strategic (particularly economic) interest in the Middle East, it will also undermine her current cordial bilateral relations with the Syrian government in which Russia remains the latter's biggest trading partner.

There is also a balance of the rules of the game in the Syrian crisis as both the United States and Russia's government have the political will to use their country's resources, financial and military, to provide support or assistance to the respective forces they align with in the crisis. Also, the United States and Russia are permanent members of the U.N Security Council, and therefore, have veto power over any multilateral sanction on Syria they consider inimical to their strategic interest. While the U.S government voted in favour of three different United Nations Security Council resolutions to impose military sanctions against the Syrian government, Russian government vetoed against such resolutions.

Alliance have also manifested in the Syrian conflict. The United States for instance, wooed regional blocs like the E.U. and NATO as well as regional super powers in the Middle East like Saudi Arabia and Turkey to provide logistic supports, both financial and military, to rebel forces and help intensify international pressure for a multilateral sanction that would lead to foreign military intervention, to be imposed on the Assad regime. The Russian government has also coordinated international financial and military assistance for the Assad government, with the Iranian government sending about 50,000 militia fighters to assist government forces in Syria to fight the rebels, providing 'backyard' routes to help deliver Russia's sent armory to government forces in Syria in order to undermine Western sanction of arms embargo to Syrian government, and giving over US\$ 1 billion in financial and military aid to the Syrian government (Yousaf, 2012). The Chinese government also voted alongside the Russian government against any form of U.N imposed military sanction on the Assad.

The zero-sum nature of U.S and Russian governments' interests in the Syrian conflict makes the possibility of a saddle - point difficult. Both nations have contradictory interests in Syria as the success of government forces will maintain the status quo in favour of Russia, and a change of government would extend the U.S government spheres of influence in the Middle East to Syria, a country it considers crucial to her ultimate economic interest in the Middle East. This explains why both the U.S and Russia, despite agreeing to U.N Security Council resolutions on the Syrian crisis that ushered in the Kofi Annan's peace process, undermined the same process of peace building by taking sides in the conflict as well as providing both financial and military supports that escalated the crisis into a full-blown civil war. 


\section{Assessing the United States' Economic and Strategic Interests in Syria}

The Middle East is central to U.S interests because of oil, hence; the United States often finds itself directly involved in Middle Eastern affairs since the region accounts for about 23 percent of U.S oil imports. In recent years, Syria has been at the forefront of a number of important U.S policy issues in the Middle East that threatens the United States' interest in the region. The most notable is the Arab-Israeli conflict in which both nations have been at opposing sides of the conflict (Prados, 2006). Resolving the Arab-Israeli conflict is a crucial strategy to the United States in maintaining regional stability in the Middle East and the need to secure Syria's cooperation in the peace process cannot be overemphasized since Syria has been the leading Arab State in confrontation with Israel. As noted by Prados and Sharp (2005), a comprehensive settlement of Arab-Israeli issues require Syrian support or acquiescence.

The U.S Department of State report on Syria in 2005 noted that the actions of President Bashir al-Assad's regime affects the achievement of U.S goals in the region, particularly the Syrian government deliberate attempts to complicate efforts to resolve the Arab-Israeli conflict, fight international terrorism, reduce-weapons proliferation, and inaugurate a peaceful, democratic and prosperous Iraqi State. Under the Obama's administration, the United States Congress increased their calls for greater U.S engagement with Syria in order to woo Syrian leaders away from Iran, whose longstanding relationship with Syria is of great concern to US policy makers and strategists (Sharp, 2010). Despite the attempt by the U.S government to improve diplomatic ties with Syria under the Obama's administration, Syria continues to act as a "spoiler" to U.S interest in the Arab-Israeli conflict.

The strain in diplomatic ties between the United States and Syria has led to a considerable number of economic sanctions against Syria by the United States' government. On November 20, 2003, the U.S congress passed the Syria Accountability Act, which authorized the President to impose economic sanctions on Syria (Prados and Sharp, 2005). The U.S President also imposed two additional sanctions based on other legislation. One requires U.S financial institutions to severe correspondent accounts with the Commercial Bank of Syria because of money laundering concerns, while the other freezes the assets of certain Syrian individuals and government entities involved in supporting policies inimical to the United States (Prados and Sharp, 2005).

The economic sanctions against Syria have negative impact on the United States' economy. Businesses in the U.S too have continued to suffer loss as a result of their inability to do business in Syria. The Washington Post of February 22, 2008, confirmed for instance that General Electric, a U.S based Multinational Corporation, declined to bid on a Syrian government contract for the construction of power plants. Also, New York Times of August 15, 2007, reported that Turkcell, a Turkish telecommunication company with U.S citizens as its major shareholders withdrew its bid to purchase Syriatel after the United States' government sanctioned Syriatel's primary stakeholder, Rami Makluf.

Sharp (2010) further noted that the U.S sanctions under the Patriot Act against the Commercial Bank of Syria have deterred private Western banks from opening branches inside Syria. Also, sanctions have prevented U.S energy firms from making new investment in Syria's energy industry with other foreign companies, particularly from Russia and China supplanting U.S firms (Sharp, 2010). One company, Gulfsands Petroleum moved its principle office to London in order to circumvent U.S sanctions against its local partner, Rami Makluf. With the exception of certain specified goods, most U.S exports to Syria are prohibited, a policy that has prevented Syria's national air carrier, Syrian Arab Airlines, both from repairing the few Boeing planes in its fleet and from procuring new planes since most Airplanes have at least 40 percent of American contents in their parts (Sharp, 2010).

The popular uprising in Syria which has now developed into a full-scale civil war provides an opportunity for the United States to assert its influence on the future of Syria in a similar vein it did in Libya with the ouster of Moummar Ghadaffi from power. Sharp and Blanchard (2012A) noted that President Obama and his Administration have been calling for Assad's resignation since August 2011, and have been vocal advocates for United Nations Security Council action to condemn the Syrian government and end the bloodshed. The United States has closed its embassy in Damascus, and Ambassador Robert Ford has left Syria. United States officials are actively participating in efforts to improve international policy coordination on Syria, such as the Friends of Syria forum and are already planning the future of Syria without Assad (Sharp and Blanchard, 2012A). The fall of Assad regime, it is expected would usher in a new government that will improve the U.S-Syria diplomatic relations; align with the U.S on how best to resolve the Arab-Israeli conflict and also secure the U.S economic interest in Syria. 
Table I: The US Government's Financial and Military Involvements in the Syrian Conflict During the Annan Peace Process.

\begin{tabular}{|l|l|}
\hline Date & Action taken \\
\hline April 2012 & $\begin{array}{l}\text { The U.S government announced that it has sanctioned the Saudi Arabia and Qatari governments to begin } \\
\text { bankrolling the opposition fighters in Syria }\end{array}$ \\
\hline April, 2012 & $\begin{array}{l}\text { The U.S' CIA and NATO soldiers reportedly supervised the movement of } 600 \text { rebel fighters from Libya to Syria in } \\
\text { order to support the rebels }\end{array}$ \\
\hline May 2012 & $\begin{array}{l}\text { The United States government provided financial assistance to non-extremist rebel groups to buy U.S made non- } \\
\text { lethal military equipments from undisclosed Gulf states that are U.S allies in the Middle East }\end{array}$ \\
\hline June 2012 & $\begin{array}{l}\text { The CIA was reported to be involved in covert operations along Turkish-Syrian border, where agents } \\
\text { investigated rebel groups and provided arms to them }\end{array}$ \\
\hline June 2012 & $\begin{array}{l}\text { The U.S government spearheaded international coordination for the provision of financial and humanitarian aids } \\
\text { worth over US\$176 million to the opposition groups in Syria under the Friend of Syria Group }\end{array}$ \\
\hline June 2012 & $\begin{array}{l}\text { The CIA was reported to be providing communications training for rebel fighters along the Turkish-Syria border } \\
\text { as well as developing supply routes for arms delivery to opposition fighters }\end{array}$ \\
\hline July 2012 & $\begin{array}{l}\text { The U.S government granted a non-governmental organization called the Syrian Support Group a license to fund } \\
\text { the free Syrian Army }\end{array}$ \\
\hline July 2012 & The State Department in the U.S reportedly allocated U.S \$ 15 million for civilian opposition groups in Syria \\
\hline July 2012 & $\begin{array}{l}\text { Operatives of the U.S Central Intelligence Agency distributed assault riffles, anti-tank rocket launchers and other } \\
\text { ammunition to Syrian opposition }\end{array}$ \\
\hline August 2012 & $\begin{array}{l}\text { US Secretary Of State, Hilary Clinton announced that the U.S has expanded operational planning to assist the } \\
\text { rebels fighting to topple Syrian President Bashir al-Assad }\end{array}$ \\
\hline
\end{tabular}

Source: Adibe (2013:35-36)

Apart from direct or indirect involvement of the US government in arming the Syrian rebels, attempts to woo international and multilateral supports to further provide financial and lethal support to the opposition forces in Syria is also evident in literature. The Friends of Syria group formed in early 2012 remains a rallying point for US allies in the European Union (E.U), the Arab world, and within the Northern Atlantic Treaty Organization (NATO) to also extend military and financial assistance to opposition fighters in Syria (Epps, 2012). In June 2012, Reuters suggested that the prospect British special forces entering Syria on the ground is growing, following unconfirmed reports from Israeli website that SAS commandos were conducting covert operations within Syrian territory (Epps, 2012).

Also within the Arab world, U.S allies have also helped the rebel fighters in their attempt to topple Assad's government. In May, 2012, the new Turkish government offered weapons, money and potential volunteers. Also, in a bid to strengthen her diplomatic relations with the United States, Qatar was reported to have shipped arms to Sunni Islamists in Syria (Epps, 2012).

\section{Assessing Russian Government's Economic and Strategic Interests in Syria}

Russia's approach towards the crisis in Syria has attracted much criticism in Western and some Arab capitals. Russian government has supported a United Nations-led process to establish a political solution in Syria, but has refused to back any demand that President Bashir al- Assad step down as a precondition for talks (Nicoll, 2012). Russia's stance on Syria is informed by a number of considerations and interests. Gorenburg (2012) noted that Russia does have extensive economic interests in the Middle East, and especially in Syria. The most important spheres are sales of military equipment and energy. The Middle East is the second largest market for Russian arms exports and the total value of unfulfilled arms contracts with Syria is estimated at 4 billion U.S dollars (Gorenburg, 2012).

Syria was Russia's second-largest arms customer in 2011, after China. Syria accounted for 15 percent of total sales valued at US\$. 3.7 billion. The sales included air-defense systems, anti-ship missiles, helicopters and tank upgrades. The sum of these deliveries dwarfed Russian sales to the rest of the Middle East, including Algeria, Iraq, the UAE, Jordan and Egypt. Russia has a reasonable expectation of continuing sales to Syria because its military equipment is well established within the Syrian armed forces. Western sanctions on Syria have also increased the opportunity for Russia's oil, gas and power firms to invest in the country (Nicoll, 2012).

Russia's economic interests in Syria extend far beyond the military sphere with a total value of approximately US\$20 billion. Russian companies have made extensive investments in oil and gas exploration and production in Syria 
(Connell and Zalasky, 2008). Russian firms play a vital role in the Syrian economy as the nation remains Syria's biggest partner. Russian companies are involved in nuclear energy projects in Syria, including plans announced in 2010 to build Syria's first nuclear power plant and continuing service of energy producing facilities it has built in the country (Gorenburg, 2012). In the manufacturing, aviation and agricultural sectors of the Syrian economy, Russian firms also dominate. For instance, a Russian manufacturing company, Uralmash signed a contract in 2010 to provide drilling equipments for a Syrian petroleum company. A plan for a joint venture with a Syrian company to build agricultural equipment was also announced by another Russian company, Traktomye Zavody (Gorenburg, 2012).

Russsian policy towards Assad regime, as noted earlier, is grounded more in maintaining and perhaps expanding its influence in the middle East as part of it's attempts to revitalize its international status vis a vis the West (Rabil, 2011). Russian exporters fear that regime change in Syria would lead to the loss of contracts, as new rulers may likely pursue economic ties with their patron, the United States. As noted by Gorenburg (2012), this is especially a concern for weapons sales, where Russia can point to Libya as an example of the economic impact of a government overthrow on Russian arms sales. Libya had purchased over US\$2billion worth of Russian weapons between 2005 and 2010 and was in advanced negotiations for additional US\$2 billion worth of contracts for a full range of weapons, including fighter jets, helicopters, submarines, tanks, and missiles. The new Libyan government, on the other hand, recently concluded a longterm defense cooperation agreement with France that may lead to the purchase of French fighter jets (Gorenburg, 2012). From this perspective, Russian leaders firmly believe that it is too late for them to abandon Assad at this point since Russia's economic interests in Syria can be maintained only if Assad defeats the opposition or there is a negotiated settlement.

The Middle East's role as an energy exporter directly affects Russia's economic interests since Russia is also an oil exporting country with oil and gas exports providing for 40 percent of Russia's federal budget, 20 percent of its GDP and constituting about 60 percent of its export (Connell and Zalasky, 2008). Russia wants to keep the world price of oil and gas high and frustrating the Arab Israeli peace process will enhance its political leverage in the Middle East. To this end, American's failures in the Middle East would likely create the kind of instability that will put Russia in a position of relative strength (Connell and Zalasky, 2008). The role of Assad's Syria in frustrating a U.S sanctioned truce that would end the Arab-Israeli conflict makes the country of strategic interest to Russia.

Table II: Russian Government's Military Involvements in the Syrian Conflict During the Annan Peace Process.

\begin{tabular}{|c|c|}
\hline Date & Action taken \\
\hline April 2012 & $\begin{array}{l}\text { It was reported in late April that Russia sent military and technical advisers to train Syrian soldiers to use supplied } \\
\text { Russian-made weapons and to help repair and maintain Syrian weapons. }\end{array}$ \\
\hline May, 2012 & A Russian cargo ship loaded with weapons from Russia to Syria arrived at a Syrian port \\
\hline June , 2012 & $\begin{array}{l}\text { Russia announced it was starting joint war games inside Syria that involved a total of } 400 \text { planes and 1,000 tanks } \\
\text { in conjunction with the Syrian army, the Chinese and Iranian armies respectively. }\end{array}$ \\
\hline June 2012 & $\begin{array}{l}\text { Russia announced that all arms and ammunition used in the joint war exercise would be stocked in Syria. Some of } \\
\text { these arms include Russian atomic submarines, warships, aircraft carriers and mine-clearing destroyers }\end{array}$ \\
\hline June , 2012 & $\begin{array}{l}\text { Reports of Russian government assistance in printing \& supplying of Syrian currency to the Assad regime in order } \\
\text { to ease the burden of economic sanctions imposed on the regime by the U.S. and her allies. }\end{array}$ \\
\hline July 2012 & $\begin{array}{l}\text { Russia announced that in keeping with its contractual obligations, it will continue to supply Syria with arms and } \\
\text { military hardware, including anti-aircraft defense systems }\end{array}$ \\
\hline July 2012 & A Russian ship, the Alaed, reportedly made shipment of attack helicopters to Syria \\
\hline July, 2012 & $\begin{array}{l}\text { A Russia licensed arms importing company, Roseboroexport, confirmed it has sent some military engineers and } \\
\text { personnel to Syria to repair Syrian helicopter gunships under an old contract }\end{array}$ \\
\hline July 2012 & $\begin{array}{l}\text { Reports of Russian government's provision of financial aid to the Assad regime to enable the Syrian government } \\
\text { pay soldiers and mercenaries fighting for the government }\end{array}$ \\
\hline July 2012 & $\begin{array}{l}\text { Reports of the Russian government coordinating international financial assistance from regimes friendly to the } \\
\text { Assad led Syrian government such as Iran and Venezuela }\end{array}$ \\
\hline August 2012 & $\begin{array}{l}\text { It was reported that "Russian military advisers" were inside Syria, manning some of the anti-aircraft defenses sent } \\
\text { by Russia }\end{array}$ \\
\hline August 2012 & $\begin{array}{l}\text { Reports of the Russian government allowing the Syria government to purchase more arms from Russia on loan } \\
\text { despite the latter's huge debt profile to the former }\end{array}$ \\
\hline
\end{tabular}

Source: Adibe (2013:37-38)

Apart from arms aid, Russia, with the assistance of some allies, particularly Iran have also provided Syria with financial 
aids to help the Assad government overcome the burden of economic sanctions imposed by the US government, the E.U, and some Arab nations. In June, 2012, Reuters reported that Russia had begun printing new Syrian pounds and that an initial shipment of bank notes had already arrived. On August $3^{\text {rd }}, 2012$, the official Syria news agency, SANA reporting from a news conference in Moscow, quoted Syrian officials acknowledging that Russia is printing money for Syria. The Russian government also publicly acknowledged a report by a non-profit investigative news organization, ProPublica that Russia shipped 240 tons of newly printed Syrian money between when the Annan peace plan became operational and December, 2012 (Yousaf, 2012). Such financial aid was aimed at helping the Syrian government to pay soldiers as well as mercenaries fighting alongside government forces.

\section{The Implication of the Divergence on Military and Financial Assistance by the United States and Russian Governments on the Annan Peace Process in Syria}

As earlier stated, the divergence in both military and financial assistance by the United States and Russia as well as their allies in the Syrian conflict compromised the enforcement of the Annan peace plan for Syria and created a humanitarian situation in the country as a result of the escalation of armed conflicts in the civil war. On April 10,2012, when the Syrian government was supposed to pull back its forces from towns in line with the ceasefire it agreed to in the Annan peace deal, Al Arabiya news agency reported that twelve members of the Syrian security forces were killed as clashes ensued in several regions. In another report by the Syrian Observatory for Human Rights, rebel fighters besieged a border checkpoint at the village of Salamah, in Aleppo province near Turkey, killing six members of the security and customs services.

The U.N acknowledged that in the first week of the ceasefire period, both the Syrian government and rebel forces violated the agreement resulting in several dozen casualties. Al Arabiya report of April 29, 2012, also confirmed increasing violence in the first week of the ceasefire period with over 69 deaths recorded as a result of gunfire by both parties in the conflict. In the month of May, 2012, violence also intensified. According to the United Nations, 108 people were killed, including 34 women and 49 children after artilleries and tanks were used by government forces to invade two opposition controlled villages in the Houla Region of Syria. In August, 2012, U.N investigators released a report which stated that the Syrian troops and Shabiha militia were responsible for the massacre.

Following the Houla massacre of 25 May, 2012, and consequent FSA ultimatum to the Syrian government, the ceasefire practically collapse as the FSA began nationwide offensives against government troops and on 1 June, 2012, President Assad vowed to crush the anti-regime uprising following the FSA announcement that it was resuming defensive operations (Mood, 2012). By the end of May, 2012, there were approximately 61,000 Syrian refugees in neighbouring countries registered with the office of the United Nations' High Commissioner for Refugees (UNHCR), and approximately 20,000 more Syrian refugees who are unregistered. This is a sharp increase from 16,000 registered and unregistered refugees before the Annan plan was accepted by the conflicting parties (Sharp and Blanchard, 2012A). On June 5, 2012, fighting broke out in Haffa and nearby villages in the coastal province of Latakia. Rebels fought with government forces backed by helicopter gunships in the heaviest clashes in the province since the revolt began (Mood, 2012). Syrian forces seized the territory from rebels following eight days of fighting and shelling.

Mood (2012) also noted that on 6 June, 2012, 78 civilians were killed in the Al-Qubeir massacre. According to activist sources, government forces started by shelling the village before the Shabiha miltia moved in. The U.N observers headed to Al-Qubeir in the hope of investigating the alleged massacre, but they were met with a road block and small arms fire before reaching the village and were forced to retreat (Mood, 2012).

Al Arabiya report of same day noted that conflict had began moving into the two largest cities in Syria, Damascus and Aleppo, an indication that there is a balance of strength between rebel and government forces involved in the conflict. On June 22, 2012, Turkish Prime Minister, Recep Tayyip Erdogan, confirmed that a Turkish F-4 fighter jet was shot down by Syrian government forces, killing both pilots. The incident escalated tension across the Turkey-Syrian border where there were reports of clashes between government forces and rebels, with the Syrian government accusing Turkey of aiding rebels across the border (Mood, 2012).

By mid-July 2012, fighting had spread across the country. Acknowledging this, the International Committee of the Red Cross (ICRC) declared the conflict a civil war. Fighting also intensified in Damascus with a major rebel push to take the city. On 18 July, 2012, Syrian Defence Minister, Hasan Turkmani, and the President's brother -in-law, General Assef Shawkat were killed by a bomb attack in Damascus. The Syrian intelligence Chief, Hisham Ikhtiyar, who was injured in the same explosion, later succumbed to his wounds. The FSA claimed responsibility for the attack (Mood, 2012). On July 19, 2012, Iraqi officials reported that the FSA had gained control of all four border checkpoints between Syria and Iraq, increasing concerns for the safety of Iraqis trying to escape the violence in Syria. In late July, government forces 
managed to break the rebel offensive on Damascus by pushing out most of the opposition fighters and on 25 July, 2012, multiple sources reported that the Assad government was using fighter jets to attack rebel positions in Aleppo and Damascus. The report was confirmed by UN observers in Syria on August 1, 2012, when it reported that government fighter jets fired on rebels in Aleppo (www.wikipedia.com/battlesofdamascusandaleppo).

Bombings have also been carried out during the Syrian civil war and both government and the opposition have been accused perpetrators. About 69 suicide bomb attacks were recorded between the period a ceasefire deal was agreed to and the end of November 2012, with the Al-Nusra Front, an extremist Islamic group opposed to the Syrian government taking responsibilities for over 75 percent of the bomb attacks. This is a clear indication of the intensification of violent conflict in Syria during the Annan peace process.

Table III: Selected List of Some Deadly Bombings in Syria During the Annan Peace Process

\begin{tabular}{|l|l|l|}
\hline Date & Nature of bomb attacks & Casualties \\
\hline April 27, 2012 & $\begin{array}{l}\text { A suicide bomb attack in Damascus was targeted } \\
\text { against the Syrian military }\end{array}$ & 9 people were reported killed \\
\hline April 30,2012 & A car bomb targeting the Syrian military in Idlib exploded & 20 people reported killed \\
\hline May 10,2012 & $\begin{array}{l}\text { Suicide bombers outside a military intelligence complex } \\
\text { in Damascus detonated a pair of car bombs tearing off } \\
\text { the facade off a 10-storey building }\end{array}$ & $\begin{array}{l}\text { With } 55 \text { people confirmed dead, and almost } 400 \text { others } \\
\text { injured, it is the deadliest in the Syrian conflict till date. }\end{array}$ \\
\hline May, 19, 2012 & $\begin{array}{l}\text { A car bomb blast struck a parking lot for a military } \\
\text { intelligence complex in the Syrian city of Deirez-Zor }\end{array}$ & 9 people were reported killed by the blast \\
\hline July 18, 2012 & $\begin{array}{l}\text { A bomb planted at the National Security Headquarters in } \\
\text { Damascus where senior officials were meeting exploded }\end{array}$ & $\begin{array}{l}\text { 4 senior military officers in Assad government including } \\
\text { his brother-in-law were reportedly killed in the blast }\end{array}$ \\
\hline
\end{tabular}

Source: www. wikipedia.com/listofbombingsinthesyriancivilwar.

During the April 2012 offensive by the Syrian Army, which preceded the expected ceasefire of 10 April contained in the Kofi Annan peace plan, the flow of refugees to Turkey reached its peak, with as many as 2,300 refugees on 4 April and 2,800 refugees on 5 April being displaced into Turkey's border areas. The number of Syrian refugees in Turkey reached 23,835 by 6 April, and about 25,000 by 10 April, when Kofi Annan visited the refugee camps in Turkey (UNHCR, 2012). There were 8,594 Syrian refugees reported to have reached Lebanon. The number of Syrian nationals in Jordan was estimated at 90,000 to 100,000 . The total official U.N number of registered refugees reached 42,000 by April, while unofficial estimates stood at as many as 130,000. Aljazeera network estimated the number of Syrian refugees at 50,000 to 60,000 . On 10 April, it was reported that the number of Syrian refugees in Syria's four neighboring countries jumped by 40 percent within the past few weeks and stood at about 55,000 registered refugees, almost half of whom were under 18 years old, according to U.N figures. There were also estimated to be at least 20,000 refugees who were not registered at the time, as well as 200,000 or more Syrians who were internally displaced inside Syria.

Table IV: Statistical Snapshot of Humanitarian situation in Syria before and after the Collapse of the Annan Peace Process

\begin{tabular}{|l|c|c|c|}
\hline Humanitarian issues & Before Annan plan & The End of Annan plan & Source \\
\hline Death toll & 8000 & 70,000 & U.N. OCHA \\
\hline U.N Registered Refugees & 42,000 & 130,000 & UNHCR \\
\hline Internally displaced & 230,000 & $1,000,000$ & ICRC \\
\hline Syrian Refugees in Turkey & 25,000 & 43,000 & UNHCR \\
\hline Syrian Refugees in Lebanon & 8,594 & 28,100 & UNHCR \\
\hline Syrian Refugees in Iraq & 3,171 & 6,500 & UNHCR \\
\hline
\end{tabular}

Source: Compiled by the Authors from cited sources on $3^{\text {rd }}$ February, 2013

\section{Conclusion}

This work examined the link between the U.S and Russian governments' involvement in the Syrian crisis and the U.N'S Kofi Annan peace process and contended that the divergence on financial and military support by the US and Russian governments heighten violent conflict in Syria during the Annan peace process, and as such, undermined the compliance 
of both the government forces in Syria and opposition rebel groups to the ceasefire agreement contained in the Annan peace deal. The zero-sum nature of the U.S and Russian governments' strategic and economic interests in Syria makes political settlement elusive since the success of any U.N sanctioned third party intervention in internal conflicts is dependent on the ability of its key members to have a consensus on the possible best course of action.

The United States and Russian governments are permanent members of the U.N Security Council that ratified the Annan peace process and as such, their actions contravened the U.N resolution on the Syrian conflict. Also, this work revealed that attempts to woo international and multilateral involvement in the Syrian conflict by the US and Russian governments have been on partisan basis, further undermining the prospect of a third party mediated peace process in Syria.

In view of the above findings, we put forward these recommendations for policy implementation:

- that the zero-sum nature of the Syrian conflict in which both the regime and its opponents seek total victory and envision a future Syrian government that excludes the other make political settlement elusive. Thus, there's need for a negotiated solution that will involve a compromise agreement by the conflicting parties on the basis of mutual consent, to create a national unity government.

- Since the success of any U.N brokered peace deal is heavily dependent on the ability of its key members to have a consensus, there is need for the U.N Security Council to galvanize international consensus on how best to approach the Syrian conflict and such consensus should be comprehensive to also accommodate regional powers in the Middle East as well as powerful international organizations like the EU and NATO.

- Any peace plan deal aimed at ending the Syrian conflict should have a time frame for implementation and not be open-ended. Such deal should also not be on the basis of the involved parties acting in good faith, but on written commitments of involved actors with prescribed penalty for violators of the peace deal. This will enable a better assessment of the enforcement process.

- There is need for the United Nations to impose an embargo on all forms of military (lethal and non-lethal) sales and aids to both rebel forces and the Syrian government until the conflict is resolved as well as sanction any nation that violates the embargo. The U.N should also outlaw any form of foreign intervention that will contradict or undermine a U.N sanctioned peace process.

\section{References}

Adibe, R.C (2013) 'The United States and Russian Governments' Involvement in the Syrian Conflict and the United Nations' Kofi Annan Peace Process" A Doctoral Seminar Paper Presented to the Department of Political Science, University of Nigeria, Nsukka. 30th July

Connell, M and Zalasky, G (2008) "Russia, China and India: Strategic Interest in the Middle East" A Paper Presented at the CNA Workshop on Regional Issues in Tampa, Florida. 24th July.

Dunne, C. (2012) The Syrian Crisis: A Case for Greater U.S Involvement. New York: Freedom House

Epps, P (2012) "Analysis: Syria's Assad Faces Growing Rebel, Foreign Threat". http://www.reuters.co.uk/thesyriancivilwar. (Retrieved on ${ }^{1 \text { st }}$ December, 2012)

Gorenburg, D (2012) "Why Russia Supports Repressive Regimes in Syria and the Middle East" in PONARS Eurasia Policy Memo. 198

ICRC, Humanitarian Report on Syria, 2012

Mood R (2012) "Kofi Annan Peace Plan for Syria". http://www.wikpedia.com/unarableaguepeaceenvoyforsyria. (Retrieved on 1st December, 2012)

Nicoll, A (2012) "Russia's Syrian Stance: Principled Self-Interest" in Journal of the International Institute for Strategic Studies. 18

Plano, J and Riggs, R (1973) Dictionary of Political Analysis. Illinois: The Dryden Press Inc

Prados, A (2006) Syria: U.S Relations and Bilateral Issues. Washington DC: Congressional Research Service

Prados, A and Sharp, J (2005) Syria: Political Condition and Relations with the U.S After the Iraq War. Washington DC: Congressional Research Service

Rabil, R. (2011) Russia Seeks Syrian Foothold in Middle East. London: Palgrave Macmillan

Sharp, J and Blanchard, C (2012A) Syria: Unrest and U.S Policy. Washington DC: Congressional Research Service

Sharp, J and Blanchard, C (2012B) Armed Conflict in Syria: U.S and International Response. Washington DC: Congressional Research Service.

Sharp, J. (2010) Syria: Background and U.S Relations. Washington DC: Congressional Research Service.

Shelling, $T$ (1960) The Strategy of Conflict. Cambridge: Harvard University Press.

UN OCHA, Humanitarian Report on Syria, 2012

UNHCR, Humanitarian Bulletin, 2012.

Varma, S.P (1975) Modern Political Theory. New Delhi: Vikas publishing House

Yousaf, F (2012) "Russia and China Vow to Protect Syria from Becoming Another Libya". http://www.wikipedia.com/foreigninterventionin thesyrianconflict. (Retrieved on 1st December, 2012) 